\title{
Dampak penggunaan e-filling terhadap kepatuhan wajib pajak: peran perilaku wajib pajak sebagai variabel mediasi
}

\author{
Doddy Setiawan ${ }^{1}$, Bobby Kurniawan ${ }^{2}$, Payamta ${ }^{3}$ \\ Fakultas Ekonomi dan Bisnis, Universitas Sebelas Maret, Surakarta, Indonesia \\ E-mail: ${ }^{1}$ doddy.setiawan@staff.uns.ac.id; ${ }^{2}$ sahabatbobby@gmail.com; ${ }^{3}$ kappayamta@yahoo.com
}

\section{A R T I K E L I N F O}

Article history:

Available online

Keywords:

Perceived usefulness, perceived

ease of use, taxpayers'

compliance, intention to behave

DOI:

https://doi.org/10.20885/jaai.vol2

2.iss1.art2

\section{A B S T R A C T}

This research aims at examining the effect of perception of the use of electronic filling (efilling) on taxpayers' compliance. Further, the study investigate the role of intention to use as mediating variable on the relation between perception of e-filling and taxpayers' compliance. Perception of the use of e-filling divide into: perceived usefulness and perceived ease of use. Sample of the study are individual taxpayer with taxpayer registration number. The study conducted at regency at Central Java Province consist of Surakarta, Boyolali, Sukoharjo, Klaten and Karanganyar. The sample of the study consists of 750 taxpayers. The study use SEM analysis to test the hypothesis. The result of the study show that that both perceived usefulness and perceived ease of use have positive effect on taxpayers' compliance and intention to behave mediate the relationship between perceived usefulness and perceived ease of use on taxpayers' compliance.

\section{Pendahuluan}

Pertumbuhan penerimaan pajak di Indonesia dari tahun ke tahun semakin meningkat, hal ini menunjukkan peranan penting pajak sebagai sumber penerimaan kas negara. Data APBN 2016 yang bersumber dari Kementerian Keuangan Republik Indonesia (2016) menunjukkan bahwa total pendapatan dalam negeri dari penerimaan perpajakan sebesar Rp 1.822,5 triliun, yang bersumber dari penerimaan perpajakan sebesar Rp 1.546,7 triliun dan penerimaan negara bukan pajak sebesar Rp 273,8 triliun dan penerimaan hibah sebesar Rp 2,0 triliun. Kondisi ini menunjukan pajak merupakan sumber pemasukan utama bagi negara. Oleh karena itu, keterlibatan peran serta masyarakat dalam membayar kewajiban perpajakan merupakan kunci penting bagi negara dalam mengatur roda pembangunan yang sedang atau akan berjalan.

Pada tahun 2015, jumlah orang pribadi yang terdaftar sebagai pajak adalah 30.044.103 orang. Jumlah penduduk Indonesia yang bekerja sebanyak 93,72 juta orang. Jumlah Wajib Pajak (WP) di Indonesia hanya 29,4\%. Jumlah ini masih tergolong minim. Menteri Keuangan Sri Mulyani Indrawati menyatakan bahwa jumlah WP yang wajib melaporkan Surat Pemberitahuan Tahunan (SPT) adalah 18 juta orang (Jefriando, 2016). Sedangkan yang menyampaikan SPT hanya 60,27\% dari WP yang wajib SPT. Hal ini menunjukkan masih rendahnya kesadaran untuk menyampaikan SPT. Saad (2014) juga menunjukkan bahwa di negara lain, seperti Australia dan Singapura, 
tingkat kepatuhan pajak juga masih sangat rendah, hal ini terlihat dari pelaporan dan penyampaian SPT hanya sekitar $45 \%$ dan Singapura hanya $54 \%$ dari total seluruh wajib pajak di negara tersebut. Rendahnya tingkat kepatuhan wajib pajak dalam menyampaikan SPT, mendorong pemerintah mencari cara untuk mengatasi masalah tersebut. Langkah yang diambil oleh pemerintah adalah dengan menggunakan perkembangan teknologi yang ada sebagai sarana bagi WP dalam menyampaikan SPT nya (Sesa, Upa, \& Tjahjono, 2015). Otoritas pajak di seluruh dunia menggunakan sistem administrasi perpajakan elektronik untuk berinteraksi dengan wajib pajak dalam pengumpulan pajak, administrasi dan tata cara kepatuhan (Ling \& Nawawi, 2010). Sistem e-filling merupakan aplikasi e-government yang digunakan di berbagai negara untuk meningkatkan kepatuhan perpajakan. Sistem seperti ini sangat menguntungkan bagi pemerintah karena sistem e-filling mengurangi jumlah data pajak yang tidak komplit dan dapat membantu penghitungan pajak secara online (Tallaha, Shukor, \& Hassan, 2014).

Saat ini pemerintah perlu melayani masyarakat melalui teknologi internet guna meningkatkan efektifitas, efisiensi, dan meyakinkan masyarakat khususnya pada tingkat transaksi (Chen et al., 2015). Ojha, Sahu, dan Gupta (2009) menunjukkan bahwa sistem e-filling telah membantu departemen perpajakan dalam menyelesaikan pengolahan SPT pajak penghasilan dan penerbitan pengembalian dana lebih pada waktu yang tepat. Selain itu, efilling juga akan berfungsi sebagai sumber otentik, komprehensif dan terkait keuangan, bisnis, dan data ekonomi untuk perumusan kebijakan di pemerintahan. Hal ini telah memungkinkan departemen pajak untuk mengambil keputusan administratif kunci dalam fungsi administrasi perpajakan dan kepatuhan (Ojha et al., 2009).

Penelitian terdahulu menunjukkan hasil yang tidak konsisten. Ritsatos (2014), Saad (2014) dan Tallaha et al. (2014) menunjukkan bahwa persepsi kebermanfaatan dan persepsi kemudahan yang mengacu pada Theory Acceptance Model (TAM) oleh Ajzen (1991) dalam penggunaan sistem berpengaruh terhadap kepatuhan pajak. Sedangkan Rehman, Esichaikul, dan Kamal (2012) menemukan bahwa persepsi kebermanfaatan tidak berpengaruh terhadap keinginan untuk mengadopsi layanan e-government di Banglades. Penelitian $\mathrm{Hu}$ et al. (2009) menunjukkan bahwa persepsi kemudahan tidak berpengaruh terhadap minat WP dalam menggunakan layanan efilling.

Penerapan e-filling tidak hanya berpengaruh pada tingkat kepatuhan wajib pajak saja, namun juga berpengaruh terhadap minat perilaku wajib pajak dalam menyampaikan SPT Tahunannya kepada Direktorat Jenderal Pajak (DJP). Penelitian terdahulu yang dilakukan oleh Chen et al. (2015), Ojha et al. (2009) dan Schaupp, Carter, dan McBride (2010) menyatakan bahwa persepsi kebermanfaatan dan persepsi kemudahan berpengaruh terhadap minat perilaku pengguna atau user. Akan tetapi penelitian Lin, Fofanah, dan Liang (2011) menunjukkan bahwa persepsi kebermanfaatan tidak berpengaruh terhadap minat perilaku dengan menggunakan tempat penelitian di Gambia. Maiga dan Asianzu (2013) dengan menggunakan teori TAM berargumen bahwa minat perilaku akan mempengaruhi penerimaan seseorang terhadap suatu sistem.

Rana, Dwivedi, dan Williams (2015) menyatakan bahwa perlu eksplorasi lebih mendalam mengenai faktorfaktor yang berpengaruh pada penerimaan suatu sistem oleh masyarakat. Faktor-faktor yang perlu dieksplorasi lebih lanjut tersebut mencakup persepsi kemudahan, persepsi kebermanfaatan dan minat perilaku. Oleh karena itu, Williams, Rana, dan Dwivedi (2015) menyarankan penelitian sejenis dilakukan di negara-negara lain untuk memperoleh hasil yang lebih komprehensif mengenai faktor-faktor yang berpengaruh terhadap penerapan layanan yang berbasis elektronik. Dalam konteks Indonesia, terdapat peningkatan yang pesat dalam penggunaan e-filling oleh wajib pajak (Zatnika, 2016). Oleh karena itu, penelitian ini menguji penerapan e-filling di Indonesia. Secara lebih spesifik penelitian ini akan menguji, pertama pengaruh persepsi kebermanfaatan terhadap kepatuhan wajib pajak. Kedua, penelitian ini menguji dampak persepsi kemudahan terhadap kepatuhan wajib pajak. Selanjutnya penelitian ini menguji dampak minat perilaku wajib pajak sebagai variabel mediasi. Ketiga, penelitian ini menguji dampak minat perilaku wajib pajak sebagai variabel mediasi hubungan antara persepsi kebermanfaatan dan kepatuhan wajib pajak. Keempat, penelitian ini menguji pengaruh persepsi kemudahan terhadap kepatuhan wajib pajak dengan minat perilaku wajib pajak sebagai variabel mediasi.

\section{Tinjauan Pustaka dan Perumusan Hipotesis}

\section{E-filling}

Teknologi informasi pada waktu sekarang telah banyak digunakan dalam berbagai bidang, seperti pendidikan (eeducation) (Spitzer, 2014), bisnis/perdagangan (e-commerce) (Oliveira \& Martins, 2011), kesehatan (e-medicine) (Kellermann \& Jones, 2013), dan juga digunakan dalam bidang pemerintahan (e-government) (Bertot, Jaeger, \& Grimes, 2010). Hal ini berdampak pada penerapan teknologi informatika khususnya pada perpajakan di Indonesia dengan tujuan untuk mempermudah, mengoptimalkan, dan meningkatkan pelayanan kepada masyarakat terutama kepada wajib pajak. DJP melakukan pembaharuan secara bertahap dengan berfokus kepada pelayanan masyarakat dan pengawasan terhadap pemenuhan kewajiban perpajakan. Pembaharuan di bidang perpajakan dilakukan 
dengan adanya penggunaan sarana elektronik melalui internet yang dimulai dari pendaftaran sebagai wajib pajak (e-registration), pembayaran pajak (e-transaction dan e-payment), dan pelaporan pajak dengan Surat Pemberitahuan (e-filling) (Lie \& Sadjiarto, 2014).

Berdasarkan Peraturan Direktorat Jenderal Pajak No. PER-03/PJ/2015 (DJP, 2015) mengenai cara penyampaian SPT melalui e-filling bagi wajib pajak orang pribadi bahwa e-filling adalah suatu cara penyampaian Surat Pemberitahuan (SPT) secara elektronik untuk wajib pajak orang pribadi dengan memanfaatkan jalur komunikasi internet secara online dan realtime melalui website Direktorat Jenderal Pajak (www.pajak.go.id).

\section{Technology Acceptance Model (TAM)}

Technology Acceptance Model (TAM) merupakan model yang digunakan untuk memprediksi penerimaan penggunaan terhadap teknologi yang mengacu pada 2 (dua) variabel yaitu persepsi kebermanfaatan (perceived usefulness) dan persepsi kemudahan (perceived ease of use) yang dikembangkan oleh Davis pada tahun 1989 (Davis, 1989). Teori ini berasal dari pengembangan Theory of Reasoned Action (TRA) dari Ajzen dan Fishbein (1980). Teoh et al. (2013) menerangkan bahwa perilaku pengguna secara keseluruhan melalui sebuah teknologi informasi yang spesifik berdampak pada faktor yang menentukan apakah individu menggunakan sistem tersebut atau tidak. Davis (1989) menjelaskan bahwa persepsi kebermanfaatan (perceived usefulness) adalah tingkat kepercayaan user dalam menggunakan suatu item yang berdampak untuk meningkatkan kinerja user tersebut, sedangkan persepsi kemudahan (perceived ease of use) adalah tingkat kepercayaan user (pengguna) dalam menggunakan sistem yang mudah dan dapat dipelajari sendiri. Penelitian yang dilakukan oleh Carter et al. (2011) dan Santhanamery dan Ramayah (2015) menunjukkan bahwa TAM dapat digunakan pada konsep pengukuran egovernment seperti pelaksanaan e-filling. Technology Acceptance Model (TAM) menjelaskan bahwa terdapat 2 (dua) faktor yang memengaruhi integrasi teknologi yaitu kebermanfaatan (usefulness) dan kemudahan dalam menggunakan teknologi (ease of use) (Gangwar, Date, \& Ramaswamy, 2015). Persepsi kebermanfaatan (perceived usefulness) mengacu pada sejauh mana calon pengguna mengharapkan sistem memiliki upaya dalam mencapai target (Ojha et al., 2009). Chen et al. (2015) menerangkan bahwa sebuah sistem berguna selama sistem tersebut menyediakan manfaat atau keuntungan individu warga yang menilai manfaat dan resiko penggunaan sistem. Persepsi kebermanfaatan yang lebih baik, maka akan memudahkan untuk warga negara khususnya wajib pajak dalam menilai dan memahami nilai dalam sistem online (Chen et al., 2015). Persepsi kemudahan penggunaan (perceiced ease of use) dapat diartikan berdasarkan pada probabilitas subjektif calon pengguna dalam menggunakan sistem aplikasi tertentu yang akan meningkatkan kinerja atau pekerjaannya dalam konteks organisasi (Ojha et al., 2009).

\section{Pengaruh Persepsi Kebermanfaatan Terhadap Kepatuhan Wajib Pajak}

Penelitian terdahulu oleh Ritsatos (2014) menunjukkan bahwa persepsi kebermanfaatan dalam penggunaan sistem berpengaruh terhadap kepatuhan pajak, hal ini berarti semakin tinggi persepsi kebermanfaatan yang dirasakan oleh wajib pajak, maka akan semakin meningkatkan kepatuhan wajib pajak. Hasil ini sejalan dengan penelitian yang dilakukan oleh Gangwar et al. (2015) yang menunjukkan bahwa persepsi kebermanfaatan berpengaruh positif terhadap keinginan menggunakan layanan cloud. Jadi, persepsi mengenai kebermanfaatan berperan penting pada saat seseorang akan mengambil keputusan. Selanjutnya penelitian Chen et al. (2015) juga menunjukkan bahwa persepsi kebermanfaatan berpengaruh positif terhadap kepuasan dalam menggunakan sistem pajak online di Filipina. Lean et al. (2009) menegaskan bahwa persepsi kemudahan berpengaruh positif terhadap keinginan untuk menggunakan layanan pajak online di Malaysia. Akan tetapi penelitian yang dilakukan oleh Lin et al. (2011) tidak menemukan dampak signifikan persepsi kebermanfaatan terhadap penggunaan e-government di Gambia. Hasil Lin et al. (2011) sejalan dengan Sesa et al. (2015) tidak berhasil membuktikan bahwa persepsi kebermanfaatan dalam penggunaan e-filling berpengaruh signifikan terhadap kepatuhan wajib pajak, hal ini dikarenakan sebagian besar responden belum terlalu mengetahui dan mengenal penggunaan e-filling untuk melaporkan SPT Tahunannya dan kurangnya sosialisasi dalam penggunaan e-filling oleh DJP. Hasil penelitian Ritsatos (2014), Chen et al. (2015) dan Gangwar et al. (2015) menunjukkan pentingnya persepsi kebermanfaatan terhadap keputusan untuk menggunakan suatu layanan atau sistem. Oleh karena itu penelitian mengajukan hipotesis sebagai berikut:

$\mathrm{H}_{1}$ : Persepsi kebermanfaatan dalam penggunaan e-filling berpengaruh positif terhadap kepatuhan wajib pajak.

\section{Pengaruh Persepsi Kemudahan Terhadap Kepatuhan Wajib Pajak}

Ritsatos (2014) dan Kamleitner, Korunka, dan Kirchler (2012) berargumen bahwa persepsi kemudahan akan memberikan dampak positif terhadap kepatuhan pajak. Semakin tinggi kemudahan dalam penggunaan suatu sistem, maka akan semakin meningkatkan kepatuhan pajak. Argumentasi ini dikonfirmasi oleh Saad (2014) dengan 
menggunakan sampel penelitian di Malaysia. Selanjutnya, Rana et al. (2015) dengan menggunakan pendekatan meta-analisis juga mengkonfirmasikan pentingnya persepsi kemudahan untuk memprediksi keinginan untuk penggunakan suatu sistem. Penelitian yang dilakukan oleh dan Gangwar et al. (2015) juga menunjukkan bahwa persepsi kemudahan dalam penggunaan suatu sistem sangat berpengaruh terhadap keputusan untuk menggunakan sistem tersebut. Oleh karena itu, penelitian ini menduga persepsi kemudahan akan memberikan dampak positif terhadap kepatuhan wajib pajak. Hipotesis yang diajukan adalah sebagai berikut:

$\mathrm{H}_{2}$ : Persepsi kemudahan dalam penggunaan e-filling berpengaruh positif terhadap kepatuhan wajib pajak

\section{Pengaruh Persepsi Kebermanfaatan Terhadap Minat Perilaku Wajib Pajak}

Chen et al. (2015) menerangkan bahwa sebuah sistem berguna selama sistem tersebut menyediakan manfaat atau keuntungan individu warga yang menilai manfaat dan resiko penggunaan sistem. Persepsi kebermanfaatan (perceived usefulness) mengacu pada sejauh mana calon pengguna mengharapkan sistem memiliki manfaat dalam mencapai target (Ojha et al., 2009). Persepsi kebermanfaatan memiliki peranan dalam memengaruhi minat perilaku, hal ini mengacu pada kesediaan individu secara keseluruhan untuk mengembangkan perilaku (Davis, 1989).

Penelitian yang dilakukan oleh Lin et al. (2011) di Gambia menunjukkan bahwa persepsi kebermanfaatan berpengaruh positif terhadap minat perilaku saat penerapan e-government. Hal ini menunjukkan bahwa jika warga mempunyai persepsi yang baik mengenai e-government maka mereka menunjukkan minat yang lebih tinggi untuk menggunakan e-government (Lean et al., 2009; Rehman et al., 2012). Hasil penelitian ini sejalan dengan penelitian yang dilakukan di Taiwan yang menunjukkan persepsi kebermanfaatan berpengaruh positif terhadap perilaku penggunakan pelayanan pemerintahan dengan menggunakan model mobile ( $m$-government) (Hung, Chang, \& Kuo, 2013). Persepsi kebermanfaatan ini juga akan meningkatkan kepuasan pengguna pajak online di Yunani (Floropoulos et al., 2010) dan meningkatkan kontinuitas penggunaan sistem pajak online di Hong Kong (Hu et al., 2009). Penelitian terdahulu yang dilakukan di Indonesia oleh Lie dan Sadjiarto (2014) membuktikan bahwa persepsi kebermanfaatan dari penggunaan sistem e-filling berpengaruh signifikan terhadap minat perilaku wajib pajak. Berdasarkan uraian teori dan hasil penelitian terdahulu yang telah dijelaskan, maka hipotesis dalam penelitian ini adalah sebagai berikut:

$\mathrm{H}_{3}$ : Persepsi kebermanfaatan dalam penggunaan e-filling berpengaruh positif terhadap minat perilaku wajib pajak.

\section{Pengaruh Persepsi Kemudahan Terhadap Minat Perilaku Wajib Pajak}

Persepsi kemudahan menunjukkan keyakinan individu bahwa menggambarkan cara individu menginterpretasikan bahwa penggunaan sistem komputer membutuhkan usaha yang minimal (Fishbein \& Ajzen, 1972). Penelitian yang dilakukan oleh Lin et al. (2011) menunjukkan bahwa persepsi kemudahan berpengaruh positif terhadap minat perilaku wajib pajak di Gambia. Hal ini menunjukkan bahwa responden di Gambia menganggap kemudahan dalam menggunakan sistem e-government akan memberi dampak positif terhadap perilaku penggunaan sistem egovernment. Hasil penelitian ini konsisten dengan penelitian Hung et al. (2013) yang menunjukkan persepsi kemudahan berpengaruh positif terhadap perilaku penggunaan m-government di Taiwan. Penelitian yang dilakukan oleh Ojha et al. (2009) terhadap professional muda di India juga menunjukkan persepsi kemudahan berpengaruh positif terhadap minat penggunaan e-filling. Rana et al. (2015) yang melakukan meta analisis juga menunjukkan dampak positif persepsi kemudahan terhadap minat perilaku. Penelitian di Indonesia yang dilakukan oleh Laihad (2013) dan Lie dan Sadjiarto (2014) menunjukkan pengaruh positif persepsi kemudahan terhadap minat perilaku penggunaan pajak online. Berdasarkan kajian penelitian terdahulu maka hipotesis dalam penelitian ini adalah sebagai berikut:

$\mathrm{H}_{4}$ : Persepsi kemudahan dalam penggunaan e-filling berpengaruh positif terhadap minat perilaku wajib pajak

\section{Pengaruh Minat Perilaku Wajib pajak Terhadap Kepatuhan Wajib Pajak}

Dalam Theory of Planned Behavior (TPB), perilaku ditampilkan oleh individu karena adanya intensi atau minat untuk berperilaku. Sementara itu, munculnya minat berperilaku selain ditentukan oleh sikap dan norma subjektif, minat juga ditentukan oleh kontrol perilaku yang dipresepsikan. Ketiga komponen tersebut saling berinteraksi dan menjadi indikator untuk menentukan perilaku tertentu (Ajzen, 1991). Saad dan Haniffa (2014) menguji minat perilaku terhadap ketaatan membayar zakat pada pelaku bisnis di Malaysia. Hasilnya menunjukkan bahwa minat perilaku wajib pajak merupakan prediktor terhadap tingkat ketaatan pembayaran zakat. Hasil ini menunjukkan pentingnya minat perilaku wajib pajak terhadap kepatuhan pembayaran zakat. Hasil ini konsisten dengan penelitian Bidin, Idris dan Shamsudin (2009) yang juga menunjukkan bahwa faktor minat perilaku berpengaruh positif terhadap perilaku pembayaran zakat. Penelitian yang dilakukan oleh Bobek, Hageman dan Kelliher (2013) terhadap kepatuhan wajib pajak menunjukkan bahwa faktor personal sangat berpengaruh terhadap kepatuhan wajib pajak. 
Selanjutnya, Venkatesh, Chan, dan Thong (2012) juga menunjukkan bahwa minat perilaku berpengaruh terhadap penggunaan suatu sistem oleh pengguna. Oleh karena itu, hipotesis dalam penelitian ini mengharapkan minat perilaku wajib pajak diharapkan akan berpengaruh terhadap kepatuhan wajib pajak.

$\mathrm{H}_{5}$ : Minat perilaku wajib pajak berpengaruh positif terhadap kepatuhan wajib pajak

\section{Pengaruh Minat Perilaku Wajib Pajak Dalam Memediasi Persepsi Kebermanfaatan, Persepsi Kemudahan terhadap Kepatuhan Perpajakan}

Penelitian ini menguji lebih lanjut dampak minat perilaku terhadap hubungan antara persepsi kebermanfaatan dan persepsi kemudahan terhadap kepatuhan perpajakan. Maiga dan Asianzu (2013) berargumentasi bahwa minat perilaku akan berdampak pada penggunaan sistem yang sedang berjalan dan pada akhirnya akan mengadopsi pajak online. Hal ini menunjukkan bahwa minat perilaku wajib pajak diharapkan memediasi persepsi kebermanfaatan dan persepsi kemudahan terhadap kesuksesan pajak online. Penelitian yang dilakukan oleh Dwivedi et al. (2011) dengan menggunakan pengujian meta analisis juga menunjukkan minat perilaku memediasi hubungan antara faktor personal pemakai sistem dan penggunaan sistem tersebut. Hal ini menunjukkan pentingnya analisis minat perilaku sebagai variabel mediasi. Teori yang diajukan oleh Ajzen dan Fishbein (1980) menyatakan bahwa minat merupakan salah satu faktor determinan terhadap perilaku. Dalam konteks ini minat perilaku wajib pajak diharapkan akan menjadi pemediasi variabel persepsi kebermanfaatan dan persepsi kemudahan terhadap kepatuhan terhadap pajak. Dalam telaah literatur yang telah dilakukan oleh Williams et al. (2015) menunjukkan bahwa minat perilaku diharapkan memediasi faktor personal terhadap ketaatan pengguna. Oleh karena itu, hipotesis penelitian yang diajukan adalah sebagai berikut:

$\mathrm{H}_{6}$ : Minat perilaku wajib pajak memediasi persepsi kebermanfaatan penggunaan e-filling terhadap kepatuhan wajib pajak

$\mathrm{H}_{7}$ : Minat perilaku wajib pajak memediasi persepsi kemudahan penggunaan e-filling terhadap kepatuhan wajib pajak

Berdasarkan telaah yang telah dilakukan maka model penelitian ini adalah sebagai berikut.

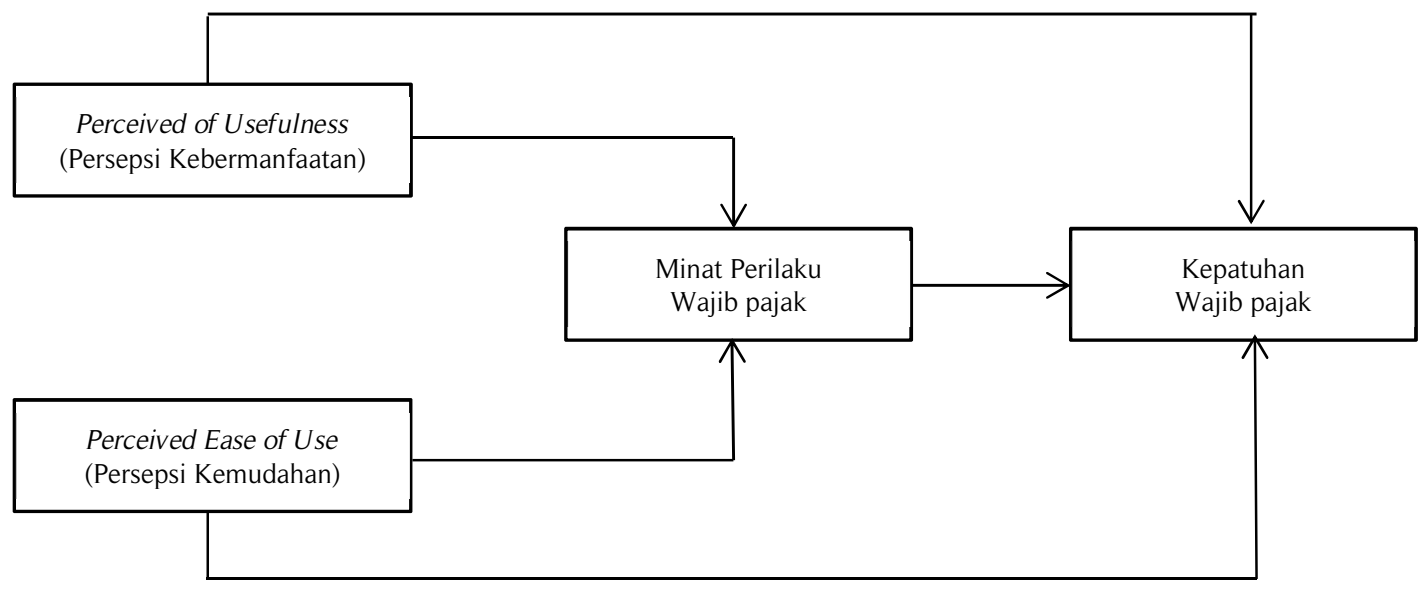

Gambar 1. Model Penelitian

\section{Metoda Penelitian}

Penelitian ini menggunakan data primer yang diperoleh dengan meggunakan daftar pertanyaan yang telah terstruktur dalam bentuk kuesioner. Objek penelitian adalah 750 wajib pajak orang pribadi pada Kantor Pelayanan Pajak Pratama Surakarta, KPP Pratama Klaten, KPP Pratama Sukoharjo, KPP Pratama Boyolali, KPP Pratama Karanganyar. Periode penelitian dimulai pada bulan April 2016 dan berakhir pada bulan Mei 2016.

Teknik analisis dalam penelitian ini menggunakan Structural Equation Model (SEM) yang dioperasikan melalui program AMOS IBM AMOS 22. Dasar penggunaan teknik SEM dalam penelitian ini adalah SEM dapat menganalisis model penelitian yang memiliki beberapa variabel independen (eksogen) dan variabel dependen (endogen).

\section{Hasil dan Pembahasan}

Bagian ini membahas mengenai statistik deskriptif penelitian ini, yang dilanjutkkan dengan analisis hasil pengujian hipotesis dan pembahasan. 


\section{Statistik Deskriptif}

Tabel 1 menunjukkan profil responden penelitian ini. Sebagian besar reponden merupakan laki-laki (68,9\%), sedangkan sisanya adalah perempuan $(31,1 \%)$. Jumlah responden laki-laki adalah sebanyak 517 orang. Selanjutnya, Tabel 1 menunjukkan bahwa sebagian besar usia responden berkisar antara 31 tahun - 40 tahun (56,9\%), sedangkan berikutnya usia reponden berkisar antara 20 tahun -30 tahun (32,3\%). Responden yang berusian lebih 40 tahun atau lebih hanya 10,8\%. Berikutnya, sebagian besar responden mempunyai tingkat pendidikan strata-1 yaitu sebesar $67,2 \%$. Responden yang mempunyai tingkat pendidikan D3, S2 dan SMA adalah 15,9\%, 10,7\% dan 6,3\%. Profile ini menunjukkan bahwa sebagian besar responden adalah laki-laki, yang berusia di antara 31 tahun 40 tahun dan memiliki pendidikan S1. Sebagian besar bekerja di lingkungan swasta yaitu 39,5\%, diikuti oleh PNS dan TNI/POLRI sebesar 28,8\% dan 17,9\%.

Tabel 1. Profil Responden Penelitian

\begin{tabular}{lcc}
\hline Jenis Kelamin & Jumlah Responden & Persentase \\
Pria & 517 & 68.9 \\
Wanita & 233 & 31.1 \\
Umur Responden & & \\
20 s/d 30 Tahun & 242 & 32.3 \\
31 s/d 40 Tahun & 427 & 56.9 \\
41 s/d 50 Tahun & 69 & 9.2 \\
> 50 Tahun & 12 & 1.6 \\
Pendidikan Terakhir & & \\
SMA & 47 & 6.3 \\
Diploma & 119 & 15.9 \\
S1 & 504 & 67.2 \\
S2 & 80 & 10.7 \\
Pekerjaan Responden & & \\
PNS & 216 & 28.8 \\
TNI/POLRI & 134 & 17.9 \\
BUMN/BUMD & 93 & 12.4 \\
Swasta & 296 & 39.5 \\
Pensiunan & 11 & 1.5 \\
Lokasi KPP & & \\
KPP Pratama Surakarta & 150 & 20.0 \\
KPP Pratama Boyolali & 150 & 20.0 \\
KPP Pratama Sukoharjo & 150 & 20.0 \\
KPP Pratama Karanganyar & 150 & 20.0 \\
KPP Pratama Klaten & 150 & 20.0 \\
Jenis SPT E-filling & & 60.5 \\
1770 SS & 454 & 39.5 \\
1770 S & 296 & \\
\hline
\end{tabular}

Tabel 2 berikut ini menunjukkan statistik deskriptif untuk masing-masing variabel

Tabel 2. Statistik Deskriptif

\begin{tabular}{lcc}
\hline \multicolumn{1}{c}{ Variabel } & Mean & Standar Deviasi \\
\hline Persepsi kebermanfaatan & 3,790 & 1,039 \\
Persepsi kemudahan penggunaan & 4,050 & 0,948 \\
Minat perilaku wajib pajak & 3,890 & 0,959 \\
Kepatuhan wajib pajak & 3,860 & 1,030 \\
\hline
\end{tabular}

Penelitian ini menggunakan 5 skala likert di kuesioner penelitian. Tabel 2 menunjukkan nilai rata-rata persepsi kebermanfaatan adalah 3,790. Hal ini menunjukkan responden menganggap tingkat kebermanfaatan e-filling tinggi. Skala likert menunjukkan nilai 1 tidak bermanfaat sampai dengan nilai 5 sangat bermanfaat. Jadi, nilai 3,790 ini menunjukkan nilai yang cukup tinggi. Persepsi kebermanfaatan ini mempunyai standar deviasi 1,039. Selanjutnya persepsi kemudahan penggunaan e-filling mempunyai 4,050 dengan standar deviasi 0,948. Nilai ini 
juga menunjukkan secara rata-rata responden menganggap sistem e-filling cukup mudah digunakan. Tabel 2 juga menunjukkan nilai rata-rata minat perilaku wajib pajak adalah 3,890. Nilai ini juga menunjukkan minat perilaku yang tinggi dalam penggunaan sistem e-filling. Nilai rata-rata kepatuhan wajib pajak adalah 3,860, sedangkan nilai tertinggi untuk kepatuhan adalah 5. Jadi, data ini menunjukkan responden cukup patuh terhadap peraturan pajak.

\section{Uji Validitas}

Uji validitas dilakukan dengan melihat nilai signifikansi $p$-value terhadap koefisien korelasinya, jika angka signifikansi $p$-value $<$ dari 0,05, maka butir pertanyaan tersebut dinyatakan valid. Penelitian ini menggunakan 4 variabel yaitu: persepsi kebermanfaatan terdiri 8 butir pertanyaan, persepsi kemudahan penggunaan terdiri dari 9 butir pertanyaan, minat perilaku wajib pajak terdiri dari 17 pertanyaan dan kepatuhan wajib pajak terdiri dari 9 pertanyaan. Hasil uji validitas persepsi kebermanfaatan, persepsi kemudahan penggunaan, minat perilaku wajib pajak, kepatuhan wajib pajak semuanya menunjukkan hasil $p$-value 0,000. Semua variabel mempunyai nilai probabilitas koefisien korelasi lebih kecil dari 0,05 . Hal ini menunjukkan semua variabel dalam penelitian ini adalah valid.

\section{Uji Reliabilitas}

Suatu konstruk atau variabel dikatakan reliabel jika nilai cronbach alpha lebih besar dari 0,60. Tabel 3 berikut ini menunjukkan hasil uji reliabilitas.

Tabel 3. Hasil Uji Reliabilitas

\begin{tabular}{llccc}
\hline No & \multicolumn{1}{c}{ Variabel } & $\mathrm{n}$ item & Alpha & Keputusan \\
\hline 1 & Persepsi kebermanfaatan & 8 & 0,955 & Reliabel \\
2 & Persepsi kemudahan penggunaan & 9 & 0,947 & Reliabel \\
3 & Minat perilaku wajib pajak & 17 & 0,977 & Reliabel \\
4 & Kepatuhan wajib pajak & 9 & 0,964 & Reliabel \\
\hline
\end{tabular}

Tabel 3 menunjukkan variabel persepsi kebermanfaatan memiliki nilai alpha sebesar 0,955. Nilai ini lebih besar dibandingkan dengan ambang batas 0,60. Jadi, variabel persepesi kebermanfaatan dalam pengujian ini sudah memenuhi reliabilitas. Selanjutnya tiga variabel lainnya, yaitu persepsi kemudahan penggunaan, minat perilaku wajib pajak dan kepatuhan wajib pajak mempunyai nilai alpha sebesar 0,947, 0,977 dan 0,964. Nilai juga menunjukkan nilai yang lebih tinggi dibandingkan ambang batas 0,60 . Dengan demikian, semua variabel dalam penelitian ini merupakan variabel yang reliable.

\section{Analisis Data}

\section{Kriteria goodness-of-fit}

Pemilihan teknik analisis SEM didasarkan pertimbangan bahwa SEM memiliki kemampuan untuk pengujian struktural model secara simultan dan efisien bila dibandingkan dengan teknik multivariat lainnya Hair, Black, Babin dan Anderson (2010). Tabel 4 menunjukkan hasil pengujian kriteria goodness-of-fit. Pengujian terhadap chi-square hitung menunjukkan hasil 131,718, sedangkan ambang batasnya adalah 132,643. Nilai chi-square hitung lebih besar dibandingkan batas kriteris, sehingga model struktur penelitian ini adalah fit. Selanjutnya pengujian probabilitas chi-square juga menghasilkan nilai sebesar $11 \%$. Nilai ini juga lebih besar dibandingkan batas $5 \%$, sehingga hal ini adapat dierima. Model penelitian ini adalah fit. Pengujian berikutnya adalah CMIN/DF atau chisquare relative juga menunjukkan nilai yang memenuhi kriteria goodness-of-fit. Nilai CMIN/DF sebesar 1,66 yang lebih kecil dibandingkan ambang batas yaitu 2. Selanjutnya pengujian GFI (goodness-of-fit index) juga menunjukkan nilai sebesar 0,980. Nilai ini lebih besar dibandingkan ambang batas penerimaan yaitu 0,900, sehingga hasil ini menunjukkan model penelitian ini fit. Pengujian terhadap RMSEA (Root Mean Square Error of Approximation), menunjukkan model penelitian ini fit karena nilainya sebesar 0,015 . Penerimaan model fit apabila nilai RMSEA lebih kecil dari 0,08. Pengujian terhadap AGFI (Adjusted Goodness-of-fit Index), FRI (Relative Fit Index), CFI (Comparative Fit Index), NFI (Normed Fit Index) dan TFI (Ticker Lewis Index) menunjukkan bahwa model penelitian ini fit. 
Tabel 4. Pengujian Goodness-of-fit

\begin{tabular}{lccc}
\hline \multicolumn{1}{c}{$\begin{array}{c}\text { Pengukuran } \\
\text { Goodness-of-fit }\end{array}$} & $\begin{array}{c}\text { Batas Penerimaan } \\
\text { Yang Disarankan }\end{array}$ & Nilai & Keputusan \\
\hline Chi-Square hitung & $\begin{array}{c}X^{2} \text { hit }<X^{2} \\
\text { tabel(df:113=132,643) }\end{array}$ & 131,718 & Fit \\
P-value Chi-Square & $\geq 0,05$ & 0,110 & Fit \\
CMIN/DF(Normed & $<2$ & 1,166 & Fit \\
chisquare $)$ & $\geq 0,90$ & 0,980 & Fit \\
GFI & $\leq 0,08$ & 0,015 & Fit \\
RMSEA & $\geq 0,90$ & 0,973 & Fit \\
AGFI & $\geq 0,90$ & 0,983 & Fit \\
RFI & $\geq 0,90$ & 0,998 & Fit \\
CFI & $\geq 0,90$ & 0,986 & Fit \\
NFI & $\geq 0,90$ & 0,998 & Fit \\
TLI & & & \\
\hline
\end{tabular}

\section{Pengujian Hipotesis}

Tabel 5 menunjukkan hasil pengujian hipotesis yang telah dilakukan dengan menggunakan alat uji SEM. Hasil pengujian persepsi kebermanfaatan terhadap kepatuhan wajib pajak menunjukkan nilai sebesar 9,164. Hasil pengujian ini menunjukkan persepsi kebermanfaatan berpengaruh positif terhadap kepatuhan wajib pajak. Semakin tinggi persepsi kebermanfaatan maka semakin tinggi tingkat kepatuhan wajib pajak. Dalam konteks penggunaan e-filling di Indonesia maka wajib pajak yang mempunyai persepsi kebermanfaatan sistem e-filling yang tinggi maka mereka akan semakin taat dalam melaksanakan pajak. Pemahaman yang baik mengenai proses e-filling akan memberikan nilai lebih bagi wajib pajak. Mereka akan lebih memahami cara penggunaan pajak e-filling dan juga keunggulan sistem e-filling. Dengan demikian maka wajib pajak akan lebih memahami manfaat penggunaan efilling, sehingga mereka akan lebih taat terhadap peraturan pajak. Hasil penelitian ini konsisten dengan penelitian terdahulu yang dilakukan oleh Chen et al. (2015), Ritsatos (2014), Lean et al. (2009) dan Saad (2014) yang menunjukkan bahwa persepsi kebermanfaatan berpengaruh positif terhadap kepatuhan wajib pajak.

Tabel 5. Pengujian Hipotesis

\begin{tabular}{|c|c|c|c|c|c|c|}
\hline No & Model & Estimate & S.E. & C.R. & $\mathrm{P}$ & Keputusan \\
\hline 1 & $\begin{array}{l}\text { Persepsi_Kebermanfaatan } \rightarrow \\
\text { Kepatuhan_Wajib pajak }\end{array}$ & 0,353 & 0,039 & 9,164 & 0,00 & $\mathrm{H}_{1}$ diterima \\
\hline 2 & $\begin{array}{l}\text { Persepsi_Kemudahan } \rightarrow \\
\text { Kepatuhan_Wajib pajak }\end{array}$ & 0,306 & 0,052 & 5,912 & 0,00 & $\mathrm{H}_{2}$ diterima \\
\hline 3 & $\begin{array}{l}\text { Persepsi_Kebermanfaatan } \rightarrow \\
\text { Minat Perilaku_Wajib pajak }\end{array}$ & 0,259 & 0,031 & 8,358 & 0,00 & $\mathrm{H}_{3}$ diterima \\
\hline 4 & $\begin{array}{l}\text { Persepsi_Kemudahan } \rightarrow \text { Minat } \\
\text { Perilaku_Wajib pajak }\end{array}$ & 0,428 & 0,042 & 10,11 & 0,00 & $\mathrm{H}_{4}$ diterima \\
\hline 5 & $\begin{array}{l}\text { Minat Perilaku_Wajib pajak } \rightarrow \\
\text { Kepatuhan_Wajib pajak }\end{array}$ & 0,300 & 0,054 & 5,564 & 0,00 & $\mathrm{H}_{5}$ diterima \\
\hline No & & ssung & $\begin{array}{c}\text { Tak } \\
\text { Langsung }\end{array}$ & & Total & Keputusan \\
\hline 1. & $\begin{array}{l}\text { Persepsi } \\
\text { Kebermanfaatan } \\
\text { Penggunaan } \rightarrow \text { Minat } \\
\text { Perilaku Wajib pajak } \rightarrow \\
\text { Kepatuhan Wajib pajak }\end{array}$ & 0,360 & & 079 & 0,439 & $\mathrm{H}_{6}$ diterima \\
\hline 2. & $\begin{array}{l}\text { Persepsi Kemudahan } \\
\text { Penggunaan } \rightarrow \text { Minat } \\
\text { Perilaku Wajib pajak } \\
\rightarrow \text { Kepatuhan Wajib } \\
\text { pajak }\end{array}$ & 0,238 & & 100 & 0,338 & $\mathrm{H}_{7}$ diterima \\
\hline
\end{tabular}


Tabel 5 menunjukkan bahwa persepsi kemudahan berpengaruh positif terhadap kepatuhan wajib pajak. Semakin tinggi tingkat persepsi kemudahan maka semakin tinggi tingkat kepatuhan wajib pajak. Hasil ini konsisten dengan ekpektasi teori TAM (Ajzen \& Fishbein, 1980; Fishbein \& Ajzen, 1972). Teori TAM menyatakan bahwa persepsi kemudahan merupakan salah satu prediktor penting pada saat adopsi suatu teknologi (Dorasamy et al., 2012; Dwivedi et al., 2011; Tallaha et al., 2014). Wajib pajak yang menganggap sistem pajak online merupakan sistem yang mudah digunakan dan dipahami maka mereka mempunyai kecenderungan akan lebih patuh terhadap pajak.

Hasil penelitian ini sejalan dengan hasil penelitian Liang dan Lu (2013) yang menunjukkan bahwa wajib pajak yang menganggap sistem pajak online mudah dimengerti akan meningkatkan keinginan untuk menggunakan pajak online. Wajib pajak sebaiknya diberikan informasi yang memadai mengenai pajak online, sehingga mereka akan memperoleh pengetahuan yang memadai. Ini akan membantu mereka dalam menggunakan pajak online. Penelitian yang dilakukan oleh Shao, Luo dan Liao (2015) di China juga menunjukkan bahwa faktor kemudahan dalam memahami pajak online berpengaruh positif terhadap minat untuk menggunakan sistem pajak online. Priantara dan Supriyadi (2012) juga memberikan bukti bahwa persepsi kemudahan dalam memiliki NPWP berpengaruh positif terhadap kepatuhan untuk mendaftarkan diri sebagai wajib pajak pribadi. Akan tetapi penelitian ini tidak konsisten dengan penelitian Anuar dan Othman (2010) yang menunjukkan persepsi kemudahan tidak berpengaruh signifikan terhadap keinginan untuk menggunakan pajak online di Malaysia.

Berdasarkan hasil pengujian yang disajikan di Tabel 5 dapat dilihat bahwa persepsi kebermanfaatan berpengaruh positif terhadap minat perilaku wajib pajak. Hal ini dapat dilihat dari nilai Critical Ratio $(C R)$ sebesar 8,358 dan nilai signifikansi Probability (P) sebesar 0,000. Hasil ini menunjukkan bahwa wajib pajak yang mempunyai persepsi kebermanfaatan yang tinggi akan mempunyai minat yang lebih tinggi terhadap penggunaan e-filling. Hasil ini sesuai dengan ekspektasi yang mengharapkan dampak positif persepsi kebermanfaatan terhadap minat perilaku wajib pajak. Hasil ini mengkonfirmasi teori TAM (Ajzen \& Fishbein, 1980; Fishbein \& Ajzen, 1972; Lin et al., 2011). Tallaha et al. (2014) juga menunjukkan bahwa persepsi kebermanfaatan berpengaruh positif terhadap minat warga negara Malaysia dalam menggunakan sistem pajak online.

Dampak positif persepsi kebermanfaatan terhadap minat perilaku ini konsisten dengan penelitian terdahulu seperti Lin et al. (2011) yang menunjukkan persepsi kebermanfaatan meningkatkan minat perilaku terhadap penerapan e-government di Gambia. Penelitian Lean et al. (2009) juga menunjukkan bahwa peningkatan persepsi kebermanfaatan pada warga negara Malaysia akan meningkatkan minat perilaku terhadap penerapan egovernment. Hasil ini juga konsisten dengan penelitian Hung et al. (2013) dan Floropoulos et al. (2010) yang menunjukkan dampak positif persepsi kebermanfaatan terhadap pemnafaatan sistem pajak online. Dalam konteks Indonesia, penelitian ini mengkonfirmasi hasil penelitian Lie dan Sadjiarto (2014) yang menunjukkan persepsi kebermanfaatan berpengaruh positif terhadap minat perilaku wajib pajak dalam penggunaan e-filling. Akan tetapi penelitian ini tidak sejalan dengan Rehman et al. (2012) yang menunjukkan persepsi kebermanfaatan tidak berpengaruh terhadap adopsi e-government di Pakistan.

Tabel 5 menunjukkan persepsi kemudahan berpengaruh positif terhadap minat perilaku wajib pajak. Hal ini dapat dilihat dari nilai Critical Ratio (CR) sebesar 10,116 dan nilai signifikansi propability P sebesar 0,000. Hasil penelitian ini menunjukkan semakin tinggi persepsi kemudahan penggunaan maka akan meningkatkan minat perilaku wajib pajak. Hasil penelitian ini mengkonfirmasi ekspektasi penelitian dan teori TAM (Ajzen \& Fishbein, 1980; Fishbein \& Ajzen, 1972; Lin et al., 2011). Hasil penelitian ini sejalan dengan penelitian Tallaha et al. (2014) yang juga menunjukkan dampak positif persepsi kemudahan terhadap minat penggunaan sistem pajak online.

Penelitian ini juga mengkonfirmasi hasil penelitian Ojha et al. (2009) yang menunjukkan kaum profesional muda di India yang mempunyai persepsi positif terhadap kemudahan penggunaan sistem pajak online akan meningkatkan minat penggunaan pajak online. Persepsi positif kemudahan penggunaan sistem juga akan meningkatkan minat perilaku wajib pajak dalam menggunakan sistem online, seperti m-government di Taiwan (Hung et al., 2013), e-government di Gambia (Lin et al., 2011). Hasil penelitian ini juga sejalan dengan hasil penelitian di Indonesia yang telah dilakukan oleh Laihad (2013) dan Lie dan Sadjiarto (2014) yang menunjukkan pengaruh positif persepsi kemudahan terhadap minat perilaku penggunaan pajak online.

Hasil penelitian ini menunjukkan bahwa persepsi kemudahan berpengaruh positif terhadap minat perilaku wajib pajak dalam menggunakan e-filling. Oleh karena itu, pemberian informasi yang memadai mengenai e-filling akan memberikan pemahaman yang memadai bagi wajib pajak bahwa sistem pajak e-filling adalah sistem yang tidak rumit. Wajib pajak yang menganggap e-filling merupakan sistem yang mudah digunakan akan mempunyai minat perilaku yang tinggi terhadap e-filling.

Tabel 5 juga menunjukkan dampak minat perilaku wajib pajak terhadap kepatuhan wajib pajak. Hasilnya menunjukkan dampak positif minat perilaku wajib pajak terhadap kepatuhan wajib pajak. Hal ini dapat dilihat dari nilai CR sebesar 5,564 dan nilai P sebesar 0,000. Hasil ini menunjukkan semakin tinggi minat perilaku wajib pajak 
maka semakin tinggi tingkat kepatuhan wajib pajak. Hal ini sejalan dengan ekspektasi Theory of Planned Behavior (TPB) seperti yang diajukan oleh Ajzen (1991) yang menyatakan minat berpengaruh terhadap tindakan. Jadi minat wajib pajak berpengaruh positif terhadap tindakan mereka yang mengikuti peraturan perpajakan dengan lebih patuh.

Hasil penelitian ini konsisten dengan penelitian Bidin et al. (2009) dan Saad dan Haniffa (2014) yang menunjukkan minat perilaku mempunyai dampak positif terhadap ketaatan membayar pajak di Malaysia. Semakin tinggi minat perilaku maka akan meningkatkan kepatuhan membayar zakat. Dampak minat perilaku yang tinggi juga mengakibatkatkan peningkatan terhadap pemanfaatan suatu sistem (Venkatesh et al., 2012), sehingga mengakibatkan bertambahnya kepatuhan terhadap sistem tersebut. Hasil pengujian hipotesis juga mengkonfirmasi Bobek et al. (2013) yang menunjukkan faktor personal berpengaruh terhadap kepatuhan wajib pajak.

Tabel 5 menunjukkan pengaruh langsung dari persepsi kebermanfaatan penggunaan terhadap kepatuhan wajib pajak sebesar 0,360 dan pengaruh langsung minat perilaku terhadap kepatuhan wajib pajak sebesar 0,244. Sedangkan pengaruh langsung dari persepsi kebermanfaatan terhadap minat perilaku sebesar 0,324. Pengaruh langsung persepsi kebermanfaatan penggunan terhadap kepatuhan perpajakan sebesar 0,360. Pengaruh tidak langsung persepsi kebermanfaatan penggunaan terhadap minat perilaku kemudian terhadap kepatuhan perpajakan $(0,244)(0,324)=0,079$, sehingga besaran total effect = langsung+tidak langsung $0,360+0,079=0,439$. Tabel 2 juga menyajikan dampak pengaruh langsung minat perilaku ke kepatuhan wajib pajak sebesar 0,238. Sedangkan pengaruh langsung dari persepsi kemudahan ke minat perilaku sebesar 0,244. Pengaruh langsung persepsi kemudahan ke kepatuhan perpajakan sebesar 0,409. Pengaruh tidak langsung persepsi kemudahan ke minat perilaku kemudian ke kepatuhan wajib pajak $(0,409)(0,244)=0,100$, sehingga besaran total effect= langsung+tidak langsung $0,238+0,100=0,338$.

Menurut Kenny (2008) dan Preacher dan Hayes (2004) apabila pengaruh variabel independen terhadap variabel dependen berkurang tetapi masih berbeda dari 0 , setelah mengontrol variabel mediator, maka dinyatakan terjadi partial mediation. Hasil penelitian ini mengkonfirmasi hipotesis yang mengharapkan minat perilaku wajib pajak memediasi persepsi kebermanfaatan dan persepsi kemudahan terhadap kepatuhan wajib pajak dalam pengisian e-filling. Hasil penelitian ini mengkonfirmasi argumentasi Williams et al. (2015) yang menyatakan minat perilaku memediasi hubungan antara faktor personal terhadap ketaatan pengguna. Penelitian yang dilakukan oleh Dwivedi et al. (2011) juga menunjukkan minat perilaku sebagai variabel mediasi pada hubungan antara faktor perilaku dan penggunaan suatu sistem.

\section{Simpulan}

Hasil penelitian ini menunjukkan bahwa persepsi penggunaan e-filling berpengaruh positif terhadap kepatuhan wajib pajak. Persepsi kebermanfaatan e-filling memberikan dampak positif terhadap kepatuhan wajib pajak. Berikutnya persepsi kemudahan dalam penggunaan sistem e-filling juga memberikan dampak positif terhadap kepatuhan wajib pajak. Hasil penelitian ini menunjukkan pentingnya persepsi wajib pajak terhadap penggunaan sistem e-filling untuk meningkatkan tingkat kepatuhan wajib pajak. Selanjutnya penelitian ini menguji peran variabel minat perilaku wajib pajak terhadap dampak persepsi penggunaan e-filling terhadap kepatuhan wajib pajak. Penelitian ini menunjukkan bahwa minat perilaku wajib pajak memediasi hubungan antara persepsi kebermanfaatan penggunaan e-filling dan kepatuhan wajib pajak. Selanjutnya minat perilaku wajib pajak juga memediasi hubungan antara persepsi kemudahaan penggunaan e-filling terhadap kepatuhan wajib pajak. Hal ini menunjukkan bahwa perilaku wajib pajak juga berperan penting untuk meningkatkan kepatuhan waib pajak.

Implikasi penelitian ini adalah sebagai berikut. Pertama, untuk meningkatkan kepatuhan wajib pajak dalam melaporkan pajaknya sebaiknya memperhatikan faktor sistem e-filling. Sangat diharapkan penggunaan e-filling memberikan manfaat yang lebih bagi wajib pajak. Apabila wajib pajak menganggap e-filling memberikan manfaat yang tinggi dalam melaporkan pajak, maka mereka akan lebih mematuhi peraturan perpajakan. Wajib pajak yang menganggap sistem e-filling lebih aman, lebih cepat kerjanya dan lebih teliti maka mereka akan melaporkan pajaknya lebih tepat waktu, dan tidak ada tunggakan pajak. Implikasi kedua, faktor kemudahan dalam penggunaan e-filling juga berperan penting untuk meningkatkan kepatuhan wajib pajak. Apabila wajib pajak menganggap pelaporan dengan e-filling itu mudah dan tidak menghabiskan waktu yang lama maka wajib pajak akan lebih taat terhadap peraturan. Implikasi ketiga adalah pentingnya memperhatikan perilaku wajib pajak. Wajib pajak yang mempunyai sikap yang baik, kontrol perilaku yang baik akan memberikan peningkatan terhadap tingkat kepatuhan wajib pajak.

Untuk meningkatkan persepsi wajib pajak terhadap penggunaan e-filling dalam pelaporan pajak, salah satu cara yang bisa ditempuh adalah dengan sosialisasi kepada wajib pajak mengenai e-filling. Sosialisasi yang intensif akan meningkatkan pemahaman mengenai e-filling. Pemahaman yang baik mengenai e-filling akan memberikan pengetahuan mengenai manfaat e-filling. Hal ini akan membantu wajib pajak dalam mematuhi 
peraturan pajak. Selain itu, wajib pajak akan menganggap e-filling bukan merupakan sistem yang sulit sehingga mereka dapat mengikuti dan melaksanakan e-filling dengan baik.

Penelitian ini fokus pada dua aspek persepsi penggunaan e-filling yaitu persepsi kebermanfaatan dan persepsi kemudahan pemakaian e-filling. Hal ini merupakan salah satu keterbatasan penelitian ini. Penelitian berikutnya bisa menambahkan faktor lain yaitu penerimaan wajib pajak terhadap terknologi informasi (Davis, 1989). Penggunaan e-filling terkait erat dengan perkembangan teknologi informasi, oleh karena itu menarik untuk melihat dampak penerimaan wajib pajak terhadap teknologi informasi terhadap peningkatan kepatuhan wajib pajak. Penelitian ini fokus pada wajib pajak pribadi sebagai sampel penelitian. Penelitian berikutnya dapat menggunakan wajib pajak badan sebagai sampel penelitian.

\section{Daftar Referensi}

Ajzen, I. (1991). The theory of planned behavior. Organizational behavior and human decision processes, 50(2), 179-211.

Ajzen, I., \& Fishbein, M. (1980). Understanding attitudes and predicting social behaviour. Englewood Cliffs, NJ: Prentice Hall.

Anuar, S., \& Othman, R. (2010). Determinants of online tax payment system in Malaysia. International Journal of Public Information Systems, 1, 17-32.

Bertot, J. C., Jaeger, P. T., \& Grimes, J. M. (2010). Using ICTs to create a culture of transparency: E-government and social media as openness and anti-corruption tools for societies. Government Information Quarterly, 27(3), 264-271. doi:https://doi.org/10.1016/j.giq.2010.03.001

Bidin, Z., Idris, K. M., \& Shamsudin, F. M. (2009). Predicting compliance intention on zakah on employment income in Malaysia: An application of reasoned action theory. Jurnal Pengurusan, 28(1), 85-102.

Bobek, D. D., Hageman, A. M., \& Kelliher, C. F. (2013). Analyzing the role of social norms in tax compliance behavior. Journal of Business Ethics, 115(3), 451-468.

Carter, L., Shaupp, L. C., Hobbs, J., \& Campbell, R. (2011). The role of security and trust in the adoption of online tax filing. Transforming Government: People, Process and Policy, 5(4), 303-318.

Chen, J. V., Jubilado, R. J. M., Capistrano, E. P. S., \& Yen, D. C. (2015). Factors affecting online tax filing - An application of the IS success model and trust theory. Computers in Human Behavior, 43, 251-262. doi:http://doi.org/10.1016/j.chb.2014.11.017

Davis, F. D. (1989). Perceived Usefulness, perceived ease of use, and user acceptance of information technology. MIS quarterly, 13(3), 319-340.

DJP. (2015). Peraturan Direktorat Jenderal Pajak No. PER-03/PJ/2015 tentang Penyampaian Surat Pemberitahuan Elektronik. http://ketentuan.pajak.go.id/index.php? $r=a t u r a n / r i n c i \& i d c r y p t=0 J \mathrm{mloZs} \% 3 D$.

Dorasamy, M., Marimuthu, M., Raman, M., \& Kaliannan, M. (2012). E-Government services online: An exploratory study on tax e-filing in Malaysia. Technology Enabled Transformation of the Public Sector: Advances in E-Government (pp. 312-325): IGI Global.

Dwivedi, Y. K., Rana, N. P., Chen, H., \& Williams, M. D. (2011). A meta-analysis of the unified theory of acceptance and use of technology (UTAUT). In M. Nüttgens, A. Gadatsch, K. Kautz, I. Schirmer, \& N. Blinn (Eds.), Governance and sustainability in information systems. Managing the Transfer and Diffusion of IT: IFIP WG 8.6 International Working Conference, Hamburg, Germany, September 22-24, 2011. Proceedings (pp. 155-170). Berlin, Heidelberg: Springer Berlin Heidelberg.

Fishbein, M., \& Ajzen, I. (1972). Attitudes and opinions. Annual Review of Psychology, 23(1), 487-544.

Floropoulos, J., Spathis, C., Halvatzis, D., \& Tsipouridou, M. (2010). Measuring the success of the Greek taxation information system. International Journal of Information Management, 30(1), 47-56.

Gangwar, H., Date, H., \& Ramaswamy, R. (2015). Understanding determinants of cloud computing adoption using an integrated TAM-TOE model. Journal of Enterprise Information Management, 28(1), 107-130.

Hair, J. F., Black, W. C., Babin, B. J., \& Anderson, R. E. (2010). Multivariate data analysis (7 ed.). USA: Pearson. 
Hu, P. J. H., Brown, S. A., Thong, J. Y., Chan, F. K., \& Tam, K. Y. (2009). Determinants of service quality and continuance intention of online services: The case of eTax. Journal of the American Society for Information Science and Technology, 60(2), 292-306.

Hung, S.-Y., Chang, C.-M., \& Kuo, S.-R. (2013). User acceptance of mobile e-government services: An empirical study. Government Information Quarterly, 30(1), 33-44. doi:http://doi.org/10.1016/j.giq.2012.07.008

Jefriando, M. (2016). Hanya 10,8 juta wajib pajak lapor SPT, Sri Mulyani: Sangat kecil. Diakses dari https://finance.detik.com/berita-ekonomi-bisnis/d-3302544/hanya-108-juta-wajib-pajak-lapor-spt-srimulyani-sangat-kecil

Kamleitner, B., Korunka, C., \& Kirchler, E. (2012). Tax compliance of small business owners: A review. International Journal of Entrepreneurial Behavior \& Research, 18(3), 330-351.

Kellermann, A. L., \& Jones, S. S. (2013). What it will take to achieve the as-yet-unfulfilled promises of health information technology. Health Affairs, 32(1), 63-68. doi:10.1377/hlthaff.2012.0693

Kementerian Keuangan Republik Indonesia. (2016). APBN 2016. Diakses dari http://www.kemenkeu.go.id/apbn2016

Kenny, D. A. (2008). Reflections on mediation. Organizational research methods, 11(2), 353-358.

Laihad, R. C. (2013). Pengaruh perilaku wajib pajak terhadap penggunaan E-filing wajib pajak di Kota Manado. Jurnal Riset Ekonomi, Manajemen, Bisnis dan Akuntansi, 1(3), 44-51.

Lean, O. K., Zailani, S., Ramayah, T., \& Fernando, Y. (2009). Factors influencing intention to use e-government services among citizens in Malaysia. International Journal of Information Management, 29(6), 458-475. doi:http://doi.org/10.1016/j.ijinfomgt.2009.03.012

Liang, S.-w., \& Lu, H.-p. (2013). Adoption of e-government services: an empirical study of the online tax filing system in Taiwan. Online Information Review, 37(3), 424-442.

Lie, I., \& Sadjiarto, A. (2014). Faktor-faktor yang mempengaruhi minat perilaku wajib pajak untuk menggunakan E-filing. Tax \& Accounting Review, 3(2), 1 - 15.

Lin, F., Fofanah, S. S., \& Liang, D. (2011). Assessing citizen adoption of e-Government initiatives in Gambia: A validation of the technology acceptance model in information systems success. Government Information Quarterly, 28(2), 271-279.

Ling, L. M., \& Nawawi, N. H. A. (2010). Integrating ICT skills and tax software in tax education: a survey of Malaysian tax practitioners' perspectives. Campus-Wide Information Systems, 27(5), 303-317.

Maiga, G., \& Asianzu, E. (2013). Adoption of e-tax services in Uganda: A model of citizen-based factors. Electronic Government, an International Journal, 10(3-4), 259-283. doi:10.1504/eg.2013.058784

Ojha, A., Sahu, G., \& Gupta, M. (2009). Antecedents of paperless income tax filing by young professionals in India: An exploratory study. Transforming Government: People, Process and Policy, 3(1), 65-90.

Oliveira, T., \& Martins, M. F. (2011). Literature review of information technology adoption models at firm level. Electronic Journal of Information Systems Evaluation, 14(1), 110.

Preacher, K. J., \& Hayes, A. F. (2004). SPSS and SAS procedures for estimating indirect effects in simple mediation models. Behavior research methods, 36(4), 717-731.

Priantara, D., \& Supriyadi, B. (2012). Faktor-faktor yang mempengaruhi pengusaha kecil dan mikro mendaftar menjadi wajib pajak orang pribadi. Jurnal Akuntansi dan Keuangan, 13(2), 98-108.

Rana, N. P., Dwivedi, Y. K., \& Williams, M. D. (2015). A meta-analysis of existing research on citizen adoption of e-government. Information Systems Frontiers, 17(3), 547-563.

Rehman, M., Esichaikul, V., \& Kamal, M. (2012). Factors influencing e-government adoption in Pakistan. Transforming Government: People, Process and Policy, 6(3), 258-282.

Ritsatos, T. (2014). Tax evasion and compliance; from the neo classical paradigm to behavioural economics, a review. Journal of Accounting \& Organizational Change, 10(2), 244-262. 
Saad, N. (2014). Tax knowledge, tax complexity and tax compliance: Taxpayers' view. Procedia-Social and Behavioral Sciences, 109, 1069-1075.

Saad, R. A. J., \& Haniffa, R. (2014). Determinants of zakah (Islamic tax) compliance behavior. Journal of Islamic Accounting and Business Research, 5(2), 182-193.

Santhanamery, T., \& Ramayah, T. (2015). Understanding the effect of demographic and personality traits on the E-filing continuance usage intention in Malaysia. Global Business Review, 16(1), 1-20. doi:10.1177/0972150914553459

Schaupp, L. C., Carter, L., \& McBride, M. E. (2010). E-file adoption: A study of US taxpayers' intentions. Computers in Human Behavior, 26(4), 636-644.

Sesa, E. S., Upa, V. A., \& Tjahjono, J. K. (2015). Pengaruh persepsi wajib pajak orang pribadi pada penerapan efiling terhadap kepatuhan dalam menyampaikan SPT tahunan di Kota Surabaya. Jurnal Gema Aktualita, $4(1), 70-78$.

Shao, B., Luo, X., \& Liao, Q. (2015). Factors influencing e-tax filing adoption intention by business users in China. Electronic Government, an International Journal, 11(4), 283-305. doi:10.1504/eg.2015.071408

Spitzer, M. (2014). Information technology in education: Risks and side effects. Trends in Neuroscience and Education, 3(3), 81-85. doi:https://doi.org/10.1016/j.tine.2014.09.002

Tallaha, A. M., Shukor, Z. A., \& Hassan, N. S. A. (2014). Factors influencing e-filing usage among malaysian taxpayers: does tax knowledge matters? Jurnal Pengurusan, 40, 91-101.

Teoh, W. M.-Y., Chong, S. C., Lin, B., \& Chua, J. W. (2013). Factors affecting consumers' perception of electronic payment: an empirical analysis. Internet Research, 23(4), 465-485.

Venkatesh, V., Chan, F. K., \& Thong, J. Y. (2012). Designing e-government services: Key service attributes and citizens' preference structures. Journal of Operations Management, 30(1), 116-133.

Williams, M. D., Rana, N. P., \& Dwivedi, Y. K. (2015). The unified theory of acceptance and use of technology (UTAUT): a literature review. Journal of Enterprise Information Management, 28(3), 443-488.

Zatnika, A. M. (2016). Laporan SPT via e-filing lampaui target. Harian Kontan. Diakses dari http://nasional.kontan.co.id/news/laporan-spt-via-e-filing-lampaui-target 